\title{
Correction to: The Dynamics and Role of Gender in High-Value Avocado Farming in Kenya
}

\author{
Beatrice Muriithi $^{1}$ D . Jane Kabubo-Mariara ${ }^{2}$
}

Published online: 18 January 2022

(c) The Author(s) 2022

\section{Correction to: The European Journal of Development Research https://doi.org/10.1057/s41287-021-00484-z}

The article "The Dynamics and Role of Gender in High-Value Avocado Farming in Kenya", written by Beatrice Muriithi, Jane Kabubo-Mariara, was originally published electronically on the publisher's internet portal on 12 November 2021 without open access. With the author(s)' decision to opt for Open Choice the copyright of the article changed on 21 of December to (C) The Author(s) 2021 and the article is forthwith distributed under a Creative Commons Attribution 4.0 International License, which permits use, sharing, adaptation, distribution and reproduction in any medium or format, as long as you give appropriate credit to the original author(s) and the source, provide a link to the Creative Commons licence, and indicate if changes were made. The images or other third party material in this article are included in the article's Creative Commons licence, unless indicated otherwise in a credit line to the material. If material is not included in the article's Creative Commons licence and your intended use is not permitted by statutory regulation or exceeds the permitted use, you will need to obtain permission directly from the copyright holder. To view a copy of this licence, visit http://creativecommons.org/licenses/by/4.0/.

The original article has been corrected.

Open Access This article is licensed under a Creative Commons Attribution 4.0 International License, which permits use, sharing, adaptation, distribution and reproduction in any medium or format, as long

The original article can be found online at https://doi.org/10.1057/s41287-021-00484-z.

Beatrice Muriithi

beatomuriithi@yahoo.com

Jane Kabubo-Mariara

jane.mariara@gmail.com

1 International Centre of Insect Physiology and Ecology (Icipe), Kenya, P.O. Box 30772-00100, Nairobi, Kenya

2 Partnership for Economic Policy (PEP), Kenya, Nairobi, Kenya 
as you give appropriate credit to the original author(s) and the source, provide a link to the Creative Commons licence, and indicate if changes were made. The images or other third party material in this article are included in the article's Creative Commons licence, unless indicated otherwise in a credit line to the material. If material is not included in the article's Creative Commons licence and your intended use is not permitted by statutory regulation or exceeds the permitted use, you will need to obtain permission directly from the copyright holder. To view a copy of this licence, visit http://creativecommons.org/ licenses/by/4.0/.

Publisher's Note Springer Nature remains neutral with regard to jurisdictional claims in published maps and institutional affiliations. 